\title{
Herpetological century: Centenary Anniversary of the Laboratory of Herpetology of the Zoological Institute of Russian Academy of Sciences
}

\author{
N. B. Ananjeva, I. V. Doronin $\bowtie$ \\ Zoological Institute, Russian Academy of Sciences \\ 1 Universitetskaya Emb., Saint Petersburg 199034, Russia
}

Article info
Short Communication
https://doi.org/10.18500/1814-6090-2021-21-
1-2-43-51
Received 15 February 2021,
revised 4 March 2021,
accepted 6 March 2021

This article is an open access article distributed under the terms and conditions of the Creative Commons Attribution 4.0 License

\begin{abstract}
The publication describes the history of the formation of the Department/Laboratory of Herpetology in the Zoological Institute of Russian Academy of Sciences and previously unknown facts of the biography of its staff. An overview of the events dedicated to the celebration of the centenary anniversary of the establishment of the Department is given.

Keywords: history of science, herpetology, Zoological Institute of Russian Academy of Sciences
\end{abstract}

Acknowledgments: The study was carried out in the framework of the State Theme of the Zoological Institute, Russian Academy of Sciences (No. AAAA-A19-119020590095-9).

For citation: Ananjeva N. B., Doronin I. V. Herpetological century: Centenary Anniversary of the Laboratory of Herpetology of the Zoological Institute of Russian Academy of Sciences. Current Studies in Herpetology, 2021, vol. 21, iss. 1-2, pp. 43-51 (in Russian). https://doi.org/ 10.18500/1814-6090-2021-21-1-2-43-51

\section{REFERENCES}

Ananjeva N. B., Darevsky I. S. Herpetological research at the Zoological Institute of the Russian Academy of Sciences. In: A. F. Alimov, ed. Fundamental Zoological Researches. Theory and Methods. Moscow, Saint Petersburg, KMK Scientific Press Ltd., 2004, pp. 27-37 (in Russian).

Ananyeva N. B., Doronin I. V. Remembered Name in Russian Herpetology. To the 125th Anniversary of S. F. Tsarevsky. Priroda, 2012, no. 6, pp. 86-92 (in Russian).

Ananjeva N. B., Doronin I. V. Ilya Sergeevich Darevsky: Portrait of Herpetologist. Photoalbum. Saint Petersburg, Zoological Institute of RAS Publ., 2015. 103 p. (in Russian).

Ananjeva N. B., Doronin I. V. Sergey Alexandrovich Chernov (1903 - 1964): Biography of herpetologist. Proceedings of the Zoological Institute RAS, 2020, vol. 324, no. 1, pp. 7-40 (in Russian).

Borkin L. J. Moscow years of P. V. Terentyev. In: O. L. Rossolimo, E. A. Dunaev, eds. Moskovskie gerpetologi [Moscow Herpetologists]. Moscow, KMK Scientific Press Ltd., 2003. pp. 385-422 (in Russian).

Borkin L. J. Lev Isaakovich Khosatzky (19131992) as a zoologist-herpetologist and paleontologist. Proceedings of the Zoological Institute RAS, 2013 a, vol. 317, no. 4, pp. 356-371 (in Russian).
Borkin L. J. World history of herpetology in biographies. Studies in the History of Biology, 2013 b, vol. 5, no. 4, pp. 102-106 (in Russian).

Darevsky I. S. My biography (herpetology and life). Proceedings of the Zoological Institute RAS, 2014, vol. 318, no. 4, pp. 292-325 (in Russian).

Darevsky I. S., Loskot, V. M. Laboratory of Ornithology and Herpetology. In: O. A. Scarlato, ed. Zoologicheskii institut. 150 let [Zoological Institute. 150 Years Old]. Leningrad, Nauka Publ., 1982, pp. 68-83 (in Russian).

Doronin I. V. The unknown life story of the eminent herpetologist. Studies in the History of Biology, 2015, vol. 7, no. 1, pp. 73-78 (in Russian).

Doronin I. V. Department of Herpetology of the Zoological Institute RAS: Disciple of K. M. Deryugin and A. M. Nikolsky. Modern Herpetology: Problems and Ways of their Solutions. Conference Proceedings of the Second International Conference of Young Herpetologists of Russia and Neighboring Countries, Dedicated to the 100th Anniversary of the Department of Herpetology of the Zoological Institute RAS. Saint Petersburg, Zoological Institute RAS Publ., 2019, pp. 47 (in Russian).

Doronin I. V. New data on some Russian herpetologists. Communication 2. Current Studies in Herpetology, 2020, vol. 20, iss. 1-2, pp. 65-76 (in Russian).

\footnotetext{
Corresponding author. Laboratory of Herpetology of Zoological Institute, Russian Academy of Sciences, Russia. ORCID and e-mail addresses: Natalia B. Ananjeva: https:/orcid.org/0000-0003-2288-0961, Natalia.Ananjeva@zin.ru; Igor V. Doronin: https://orcid.org/ 0000-0003-1000-3144, Igor.Doronin@zin.ru.
} 
Sukhova N. G. Georgy Feodorovich Sukhov (1899-1942): A biographical essay. Studies in the History of Biology, 2015, vol. 7, no. 1, pp. 63-72 (in Russian).

Ananjeva N. B. Department of Herpetology, Zoological institute, Russian Academy of Sciences, St. Petersburg, Russia: History and current research. Herpetological Review, 1998, vol. 29, no. 3, pp. 136-140.

Ananjeva N. B. History and Anniversary Dates of Russian Herpetology in St. Petersburg. Herpetologia Petropolitana. Proceedings of the 12th Ordinary General Meeting of the Societas Europaea Herpetologica. Saint Petersburg, Russia, 2005, pp. 5-10.
Adler K., ed. Contributions to the History of Herpetology. Volume 3. Issued to Commemorate the 7th World Congress of Herpetology. Vancouver, Society for the Study of Amphibians and Reptiles, 2012. 564 p.

Uetz P., Cherikh S., Shea G., Ineich I., Campbell P. D., Doronin I. V., Rosado J., Wynn A., Tighe K. A., Mcdiarmid R., Lee J. L., Köhler G., Ellis R., Doughty P., Raxworthy C. J., Scheinberg L., Resetar A., Sabaj M., Schneider G., Franzen M., Glaw F., Böhme W., Schweiger S., Gemel R., Couper P., Amey A., Dondorp E., Ofer G., Meiri S., Wallach V. A global catalog of primary reptile type specimens. Zootaxa, 2019, vol. 4695, no. 5, pp. 438-450. 